laboratory results become available. ${ }^{4}$ The use of pleural fluid levels of ADA provides a rapid and accurate method of suggesting a diagnosis of tuberculosis, especially in high prevalence areas, thereby expediting the initial decision making process and management of the patient. It is important to recognise, however, that pleural fluid levels of ADA may be high in other conditions, and particularly when the cause is a pyogenic infection.

We would like to extend our sincere gratitude to the Cape Provincial Administration for use of facilities; Dr I J M Venter for assistance with the collection of samples; and Drs J van Greune and ME Carstens for continuous and critical revision of the manuscript.

1 Küstner HGV. Epidemiological comments. Epidemiology of the Department of National Health and Population Development 1993;20:15-6.

2 Berger HW, Mejia E. Tuberculous pleurisy. Chest 1973;63: 88-92.

3 Jay SJ. Diagnostic procedures for pleural diseases. Symposium on pleural diseases. Clin Chest Med 1985;6:33-48.

4 De Wit D, Maartens G, Steyn L. A comparative study of De Wit D, Maartens $G$, Steyn $L$. A comparative study of
the polymerase chain reaction and conventional procedures for the diagnosis of tuberculous pleural effusion. Tubercle 1992;73:262-7.

5 Piras MA, Gakis C, Budroni M, Andreoni G. Adenosine deaminase activity in pleural effusions: an aid to differentia diagnosis. $B M \mathcal{F}$ 1975;3:192-3.

6 Maritz FJ, Malan C, Le Roux I. Adenosine deaminase estimations in the differentiation of pleural effusions. $S$ Afr Med $¥$ 1982;62:556-8.

7 Ocaña I, Martinez-Vazquez JM, Segura RM, Fernandez-DeSevilla T, Capdevila JA. Adenosine deaminase in pleural fluids. Test for diagnosis of tuberculous pleural effusion. Chest 1983;84:51-3.

8 Strankinga WFN, Nauta JJP, Staub JP, Stam J. Adenosine deaminase activity in tuberculous pleural effusions: a diag nostic test. Tubercle 1987;68:137-40.

9 Bañales JL, Pineda PR, Fitzgerald JM, Rubio H, Selman $M$, Salazar-Lezama $M$. Adenosine deaminase in the diag nosis of tuberculous pleural effusions. A report of 218 nosis of tuberculous pleural effusions. A report of 218

10 San José E, Valdés L, Sarandeses A, Alvarez D, Chomon B. Diagnostic value of adenosine deaminase and lysozyme in tuberculous pleurisy. Clin Chim Acta 1992;209:73-81. 11 Valdés L, San José E, Alvarez D, Sarandeses A, Pose A, Chomon B, et al. Diagnosis of tuberculous pleurisy using the biologic parameters adenosine deaminase, lysozym and interferon gamma. Chest 1993;103:458-65.

12 Van Keimpema ARJ, Slaats EH, Wagenaar JMP. Adenosine deaminase, not diagnostic for tuberculous pleurisy. Eur $\mathcal{F}$ Respir Dis 1987;71:15-8.

13 Maartens G, Bateman ED. Tuberculous pleural effusions: increased culture yield with bedside inoculation of pleural fluid and poor diagnostic value of adenosine deaminase. Thorax 1991;46:96-9.

14 Giusti G. Adenosine deaminase. In: Bergmeyer HU, ed Methods of enzymatic analysis. New York: Academic Press 1974:1092-6.

15 Burgess LJ, Maritz FJ, Taljaard JJF. Comparative analysis of the biochemical parameters used to differentiate between pleural exudates and transudates. Chest 1995 (in press)

16 Beck JR, Schultz EK. The use of relative operating characteristic (ROC) curves in test performance evaluation. Arch Pathol Lab Med 1986;110:13-20.

17 Van der Weyden MB, Kelley WN. Human adenosine deaminase distribution and properties. $\mathcal{F}$ Biol Chem 1976 251:5448-56.

18 Barton RW, Goldshneider I. Nucleotide metabolizing enzymes and lymphocytic differentiation. Mol Cell Biochem 1979;28:135-47.

19 Fischer D, van der Weyden MB, Snyderman R, Kelley WN. A role for adenosine deaminase in human monocyte maturation. $\mathcal{F}$ Clin Invest 1976;2:399-407.

20 Sahn SA. State of the art. The pleura. Am Rev Respir Dis 1988;138:184-234.

21 Yam LT. Diagnostic significance of lymphocytes in pleural effusions. Ann Intern Med 1967;66:972-82.

\title{
Posterior subcapsular cataract and inhaled corticosteroid therapy
}

\author{
Faisal Abuekteish, J N P Kirkpatrick, George Russell
}

\section{Department of Medical Paediatrics, Royal Aberdeen Children's Hospital, Foresterhill, Aberdeen AB9 2ZG, UK F Abuekteish G Russell}

\section{Department of Ophthalmology, University of Aberdeen, Foresterhill, Aberdeen AB9 2ZD, UK J N P Kirkpatrick \\ Reprint requests to: Dr G Russell. \\ Received 7 October 1994 Returned to author 5 December 1994 Revised version received 29 December 1994 Accepted for publication 20 January 1995}

\begin{abstract}
Background - Although posterior subcapsular cataract complicates both systemic and topical corticosteroid therapy, the literature on the effects of inhaled corticosteroids is conflicting.

Methods - One hundred and forty children and young adults on inhaled corticosteroids were examined by slit lamp ophthalmoscopy after pupillary dilatation; 103 had received one or more short courses ( $\leqslant 7$ days) of oral corticosteroids in the management of acute asthmatic attacks and four had also received one or more prolonged courses ( $\geqslant 4$ weeks) of alternate day oral corticosteroid therapy.

Results - Bilateral posterior subcapsular cataract was identified in one girl who had received several prolonged courses of oral corticosteroids, but was not identified in any other patient.
\end{abstract}

Conclusions - There is no evidence to support the contention that inhaled corticosteroid therapy on its own, or in association with short courses of oral corticosteroid therapy, might cause cataracts. Although children receiving long term systemic corticosteroid therapy should be screened for cataracts, this is unnecessary in children on inhaled corticosteroids alone.

(Thorax 1995;50:674-676)

Keywords: childhood asthma, posterior subcapsular cataract, corticosteroids.

The association between systemic corticosteroid therapy and the development of posterior subcapsular cataract, first described by Black et al in adults in $1960,{ }^{1}$ has also been reported in children receiving systemic corticosteroids for asthma. There are also reports 
Table 1 Ages of 140 patients on inhaled corticosteroid therapy and duration of treatment at time of examination

\begin{tabular}{lc}
\hline Age (years) & 10 \\
$\leqslant 5$ & 36 \\
$6-10$ & 66 \\
$11-15$ & 18 \\
$16-20$ & 1 \\
$21-25$ & 7 \\
$26-30$ & 2 \\
$>30$ & $12 \cdot 2(5 \cdot 9)$ \\
Mean (SD) & 70 \\
Duration of treatment (years) & 49 \\
$\leqslant 4$ & 14 \\
$5-8$ & 2 \\
$9-12$ & 4 \\
$13-16$ & 1 \\
$17-20$ & $6 \cdot 7(4 \cdot 3)$ \\
$21-24$ & \\
Mean (SD) & \\
\hline
\end{tabular}

suggesting a link between inhaled corticosteroids and posterior subcapsular cataract formation, but these are difficult to interpret, partly because most fail to define the population from which the cases are drawn, but mainly because of uncertainty regarding previous use of systemic corticosteroid therapy. However, Simons $e t a l^{2}$ found no evidence of posterior subcapsular cataract in 95 young asthmatic patients on inhaled corticosteroids, nor did

Table 2 Daily doses of inhaled corticosteroids at time of examination

\begin{tabular}{|c|c|c|c|c|c|}
\hline \multirow[t]{2}{*}{ Dose $(\mu g)$} & \multicolumn{2}{|c|}{ Beclomethasone } & Budesonide & Both & Total \\
\hline & & $\%$ & $n \quad \%$ & $n \quad \%$ & $n \quad \%$ \\
\hline $\begin{array}{l}\leqslant 200 \\
201-400 \\
401-800 \\
801-1600 \\
>1600 \\
\text { Total }\end{array}$ & $\begin{array}{r}7 \\
15 \\
16 \\
7 \\
1 \\
46\end{array}$ & $\begin{array}{r}15 \cdot 2 \\
32 \cdot 6 \\
34 \cdot 8 \\
15 \cdot 2 \\
2 \cdot 2\end{array}$ & $\begin{array}{rr}5 & 7 \cdot 5 \\
7 & 10 \cdot 4 \\
36 & 53 \cdot 7 \\
18 & 26 \cdot 9 \\
1 & 1 \cdot 5 \\
67 & \end{array}$ & $\begin{array}{rc}0 & 0 \\
7 & 25 \cdot 9 \\
16 & 59 \cdot 3 \\
4 & 14 \cdot 8 \\
0 & 0 \\
27 & \end{array}$ & $\begin{array}{rr}12 & 8 \cdot 5 \\
29 & 20 \cdot 6 \\
68 & 48 \cdot 2 \\
29 & 20 \cdot 6 \\
2 & 1 \cdot 4 \\
140 & \end{array}$ \\
\hline $\begin{array}{l}\text { Mean }(\mathrm{SD}) \text { daily } \\
\text { dose }(\mu \mathrm{g})\end{array}$ & 499 & $(365)$ & $657(355)$ & $590(252)$ & $592(346)$ \\
\hline
\end{tabular}

Although most patients had received the same drug since treatment was started, some had had both beclomethasone and budesonide at different times and these are shown separately.

Table 3 Estimated lifetime dose of inhaled corticosteroids

\begin{tabular}{|c|c|c|c|c|}
\hline \multirow{2}{*}{$\begin{array}{l}\text { Lifetime dose } \\
\left(\mu g / m^{2}\right)\end{array}$} & Beclomethasone & Budesonide & Both & Total \\
\hline & $n \quad \%$ & $n \quad \%$ & $n \quad \%$ & $n \quad \%$ \\
\hline $\begin{array}{l}\leqslant 200 \\
201-400 \\
401-800 \\
801-1600 \\
1601-3200 \\
3201-6400 \\
\text { Total }\end{array}$ & $\begin{array}{rr}13 & 28 \\
9 & 20 \\
8 & 17 \\
9 & 20 \\
5 & 11 \\
2 & 4 \\
46 & \end{array}$ & $\begin{array}{l}1522 \\
1218 \\
1319 \\
1522 \\
1015 \\
23 \\
67\end{array}$ & $\begin{array}{rr}0 & 0 \\
0 & 0 \\
622 \\
1348 \\
726 \\
14 \\
27\end{array}$ & $\begin{array}{r}2820 \\
2115 \\
2719 \\
3726 \\
2215 \\
54 \\
140\end{array}$ \\
\hline Mean dose & $869 \mathrm{mg} / \mathrm{m}^{2}$ & $8179 \mathrm{mg} / \mathrm{m}^{2}$ & $1368 \mathrm{mg} / \mathrm{m}^{2}$ & $4464 \mathrm{mg} / \mathrm{m}^{2}$ \\
\hline
\end{tabular}

"Both" refers to patients who had received both beclomethasone and budesonide at different times.

Table 4 Clinical details of four children who had received long term alternate day oral corticosteroid in addition to inhaled corticosteroids

\begin{tabular}{lcccc}
\hline & Case 1 & Case 2 & Case 3 & Index case \\
\hline Age (years) & $15 \cdot 8$ & $14 \cdot 5$ & $13 \cdot 3$ & $12 \cdot 8$ \\
$\begin{array}{l}\text { Sex } \\
\text { Duration of asthma (years) }\end{array}$ & $\mathrm{F}$ & $\mathbf{M}$ & $\mathrm{F}$ & $\mathrm{F}$ \\
$\begin{array}{l}\text { Duration of treatment with inhaled } \\
\quad \text { corticosteroid (years) }\end{array}$ & $5 \cdot 0$ & 0.9 & $9 \cdot 8$ & $4 \cdot 5$ \\
$\begin{array}{l}\text { Estimated daily dose of inhaled } \\
\quad \text { corticosteroid }\left(\mu \mathrm{g} / \mathrm{m}^{2} \text { ) }\right.\end{array}$ & 1091 & 1250 & 492 & 1267 \\
$\begin{array}{l}\text { Estimated cumulative dose of inhaled } \\
\quad \text { corticosteroid }\left(\mathrm{mg} / \mathrm{m}^{2}\right)\end{array}$ & 1991 & 411 & 1760 & 2081 \\
$\begin{array}{l}\text { Number of short courses of oral } \\
\text { corticosteroid in past year }\end{array}$ & 5 & 10 & 4 & 4 \\
$\begin{array}{l}\text { Duration of alternate day oral corticosteroid } \\
\text { treatment (months) }\end{array}$ & 6 & 7 & 18 & 5 \\
\hline
\end{tabular}

Tinkelman $e t a l^{3}$ in a multicentre study in which 102 children received beclomethasone. We report the prevalence of posterior subcapsular cataract in 140 young asthmatic patients on inhaled corticosteroids, four of whom had also received prolonged courses of oral steroids.

\section{Methods}

One hundred and fourteen children and adolescents attending the asthma clinic at the Royal Aberdeen Children's Hospital and 28 adult asthmatic subjects selected from a list of former patients who were known to have received inhaled corticosteroids for $>5$ years were invited to have their eyes examined; there was one refusal in each group, leaving a study population of 140 , of whom 81 were male and 59 were female. A detailed history of current and previous oral and inhaled corticosteroid therapy was obtained. All patients underwent an ophthalmic examination which included slit lamp biomicroscopy and direct ophthalmoscopy following pupillary dilation with tropicamide $0.5 \%$. Ethical approval was obtained from the University of Aberdeen and Grampian Health Board.

\section{Results}

One hundred and forty asthmatic patients on inhaled corticosteroids were studied between August 1992 and June 1993. Details of their ages and of the dose, cumulative dose, and duration of inhaled corticosteroid therapy are presented in tables 1-3. In addition, 103 patients had received a mean (SD) of $2 \cdot 24$ (1.91) (range $1-10)$ short courses ( $\leqslant 7$ days) of oral prednisolone for acute asthma. Details of the four patients who had also received one or more prolonged courses ( $\geqslant 4$ weeks) of alternate day oral corticosteroid therapy for intractable chronic asthma are given in table 4.

Bilateral posterior subcapsular cataracts were identified in one patient who had received frequent courses, both short and long, of oral prednisolone; her history is presented in detail below. No other cataract was found in any other patient in this study.

\section{CASE REPORT}

The patient was 13 years old at the time of ophthalmic examination. Her father had asthma and her maternal grandfather had agerelated cataracts. There was no other family history of note. She had suffered from asthma since the age of two and, from the age of six, the severity of her asthma had gradually increased. She was treated with a wide variety of medications which included sodium cromoglycate, $\beta_{2}$ agonists (including inhaled salmeterol and controlled release oral salbutamol), ipratropium bromide, sustained release oral theophylline, inhaled budesonide and beclomethasone through various inhalation devices, oral prednisolone and, because of psychological disturbance in relation to prednisolone therapy, betamethasone. She had 
required frequent admission to hospital for exacerbations of asthma, invariably receiving oral steroids, and numerous other exacerbations had been dealt with by her general practitioner using nebulised $\beta_{2}$ agonists, short courses of oral corticosteroids being required about four times a year. In May 1992 she was started on oral prednisolone $20 \mathrm{mg}$ on alternate days and, at the time of the examination five months later, she was still on prednisolone $15 \mathrm{mg}$ on alternate days and budesonide $600 \mu \mathrm{g}$ twice daily, as well as various bronchodilator inhalers and nebuliser solutions.

\section{Discussion}

Inhaled corticosteroid therapy is recommended for the prophylaxis of asthma in those children in whom treatment with cromoglycate has failed. ${ }^{4}$ However, despite the efficacy of inhaled corticosteroids, oral corticosteroids must still be used in the management of severe acute asthma ${ }^{4}$ and occasionally long term oral therapy has to be prescribed for problematic cases. It is therefore difficult to identify a substantial number of children whose corticosteroid therapy has been given exclusively by the inhaled route with the result that, whereas the association between posterior subcapsular cataract formation and prolonged systemic corticosteroid therapy has been well documented in asthmatic adults ${ }^{5}$ and children, ${ }^{67}$ the relationship with inhaled corticosteroids is much less clear.

Various dose-related systemic side effects have been observed with inhaled corticosteroids $^{8}$ and it would not be surprising if such therapy were also associated with posterior subcapsular cataract formation. However, despite the use of relatively high doses of inhaled corticosteroids in the present series, and the exposure of the majority of our patients to short courses of oral corticosteroid therapy for acute attacks, we found posterior subcapsular cataract only in association with the prolonged administration of oral corticosteroids. There were no apparent differences between the child with posterior subcapsular cataract and the other children on long term oral corticosteroids to explain why she developed cataract; cases 1 and 3 had had similar cumulative doses of inhaled corticosteroids and more prolonged treatment with alternate day oral corticosteroids, supporting the proposal that there is a personal predisposition to cataractogenesis, ${ }^{9}$ possibly based on a genetic factor. ${ }^{10}$

Taking the findings of the present study in conjunction with those of Simons et $a l^{2}$ and Tinkelman $e t a l,{ }^{3}$ the failure to identify posterior subcapsular cataract in a total of 333 $(136+95+102)$ patients on inhaled corticosteroids implies that the risk of developing this complication is extremely low, and we agree with Simons $e t a l^{2}$ in concluding that the routine ophthalmological screening of patients on inhaled corticosteroids is not warranted on present evidence.

1 Black RL, Oglesby RB, von Sallmann L, Bunim JL. Posterior subcapsular cataracts induced by corticosteroids in patients with rheumatoid arthritis. $\mathscr{f} A M A$ 1960;174:16671.

2 Simons FER, Persaud MP, Gillespie CA, Cheang M, Shuckett EP. Absence of posterior subcapsular cataracts in young patients treated with inhaled glucocorticoids. Lancet 1993, 342:776-8.

3 Tinkelman DG, Reed CE, Nelson HS, Offord KP. Aerosol beclomethasone dipropionate compared with theophylline

4 Guidelines on the management of asthma. Thorax 1993; 48(Suppl):S1-S24

5 Lindholm B, Linner E, Tengroth B. Effects of long term systemic steroids on cataract formation and on aqueou humour dynamics. Acta Ophthalmol 1965;43:120-7.

6 Rooklin AR, Lampert SI, Jaeger EA, McGeady SJ, Mansmann HC. Posterior subcapsular cataracts in steroidrequiring asthmatic children. F Allergy Clin Immunol 1979, 63:383-6.

7 Nassif E, Weinberger M, Sherman B, Brown K. Extrapulmonary effects of maintenance corticosteroid therapy with alternate-day prednisolone and inhaled beclomethasone in children with chronic asthma. $\mathcal{f}$ Allergy clinethasone in children with chronic asthma. $f$ Allerg Clin Immunol 1987;80:518-29.

8 Russell G. Inhaled corticosteroid therapy in children: an assessment of the potential for side effects. Thorax 1994; 49:1185-8.

9 Urban RC, Cotlier E. Corticosteroid-induced cataracts. Surv Ophthalmol 1986;31:102-10.

10 Fournier C, Milot JA, Clermont M-J, O'Regan S. The concept of cataractogenic factor revisited. Can $\mathcal{f} O p h$ thalmol 1990;25:345-7. 